\title{
Social network for the choice of tourist destination: attitude and behavioral intention
}

\author{
Hendy Kasima ${ }^{\text {a }}$, Edi Abdurachman ${ }^{\text {a }}$, Asnan Furinto ${ }^{\text {a }}$ and Wibowo Kosasih ${ }^{a}$
}

${ }^{a}$ Bina Nusantara University, Doctor of Research in Management, Jl. Kebon Jeruk Raya No.27, Jakarta Barat 11530, Indonesia

\begin{tabular}{l}
\hline C H R O N I C L E \\
\hline Article history: \\
Received: June 152019 \\
Received in revised format: June \\
152019 \\
Accepted: July 8, 2019 \\
Available online: \\
July 8, 2019 \\
\hline Keywords: \\
Social Media \\
Tourists' Destination \\
Decision on Destination \\
Perception \\
Impact
\end{tabular}

\section{A B S T R A C T}

Social media is one of the most important elements in the process of industry 4.0. It has transformed itself into not just a platform for social interactions, but into a powerful marketing tool. People posting pictures or information through social media will likely influence others seeing it. This research investigates the impact of social media postings on millennial (Gen Y) tourists' decision in choosing destinations, as well as the perceptions of social media users toward the information they gather from the social media about the tourism destinations. World Travel and Tourism Council in its release in 2018 revealed that tourism industry represents $10.4 \%$ of total global GDP. The industry has also contributed $20 \%$ of new jobs globally created in the last decade. The findings from samples taken from respondents in greater Jakarta (Jakarta, Bogor, Depok, Tangerang and Bekasi) show that social media contributes significantly on shaping the millennial tourists' decision in choosing their holiday destinations.

\section{Introduction}

The tourism industry is playing bigger roles and has become more important for many countries, compared with the past (Bialik \& Matsa, 2017). When other sources of gross domestic product (GDP) can diminish, tourism will be the source of renewable platform for revenues. The global improving trend of tourism has driven many countries, tourism organizations and stakeholders to promote their destinations for tourist attraction. World Travel and Tourism Council (WTTC) in its report published in March 2018 revealed that tourism industry contributes $10.4 \%$ of GDP from the total of global GDP. This amount equals to USD 8,272.3 billion, and it is forecasted to be $11.7 \%$ of GDP at the amount of USD $12,450.1$ by 2028 . The industry also provides $9.9 \%$ of global employment. The report also stated that $20 \%$ of all net jobs created in the last decade have been from the tourism and travel industry. With the potential of revenue in GDP this industry brings competition in attracting tourists. Competition in this industry is very high, with many governments and institutions spending large amount of funds to promote their tourism objects in foreign media and events. Policies have also been amended to ensure they become more competitive, and some governments even go for deregulation on the visa in order to attract more tourists. As competition grows, governments and institutions need to find more effective and efficient

* Corresponding author. Tel.: +6281519906996

E-mail address: hendyliem@yahoo.com (H. Kasim) 
ways in promoting their destinations. Aside from infrastructure and "content" of the destination, promotion and advertising play important role in attracting tourists. This is important because tourists nowadays are faced with so many options of holiday destinations to choose from many countries globally (Thai \& Yuksel, 2017). Above the line advertising has long been recognized and used as the main strategy in executing promotion of products. Television has long been recognized as effective media because of its maximum coverage. However, the emergence of the Internet, and especially social media, may or have disrupted that, although in many developing countries, television is still the primary platform used for advertising activities, despite the expensive rate. However, some studies show that the gap of consumption between television and online has been reduced. The millennials may have different pattern in consuming media and getting information. Thus, it may impact in different approach in communicating a product or service with the millennials.

Promoters and stakeholders in the tourism industry must figure out whether the so-called "traditional" media like television or print media will be the better option for the millennials, or they can use the social media to do so. The Internet or social media will definitely be a much better option in terms of the price (Wang, 2018), however its effectiveness remains a question mark for some media buyers and agencies. The question that needs answering is: Will the social media provide a better coverage for tourism promotion for the millennials? Or at least, can it provide a better value for money for that matter?

The objective of this research is to find out the impact of social media in influencing the millennial tourists' decision in choosing their holiday destination. The result of this research will be useful for marketing studies, in particular the advertising field. For the industry, it will help decision makers, media buyers or agencies and other stakeholders in the tourism and advertising industry in planning their promotion activities towards the millennials market.

\section{Literature review}

Plenty of studies have been performed about how media influences people (in the context of this research; the customer, or potential tourist). The media (including social media) influences behavior in many aspects, including the spending behavior of the consumers. The question in this research will be how the social media impact the tourists' decision making in choosing their destination. Potential tourists encounter information from the social media, be it the information they actively seek for, or the information that passes their "wall" or timeline in the social media.

Dudensing et al. (2011) conducted a survey on perceptions of tourism promotion and business challenges. The survey took place in Pennsylvania and West Virginia, United States. This study used survey data from tourism-based businesses and tourism promotion and economic development organizations in rural western Pennsylvania and West Virginia to compare how various actors perceive the most pressing tourism promotion efforts and business challenges. In general, tourism businesses and support organizations agree on the promotional needs of tourism-based businesses and hold similar perceptions about industry problems. However, tourism promotion agencies underestimate the role of the internet in promotions and perceive workforce issues differently than do businesses. In the general context of media in all industries, it can also influence perception, and in turn, influences action or behavior. Tong (2013) analyzed the impact of media in the context of the changes in initial public offering (IPO) share price on a listing day in Hong Kong. The study revealed that the IPO share price on a listing day was significantly affected by the media tones. Shares that receive positive coverage from significantly respected media are most likely to have increased in price.

The influences spread by the media in the context of this article will be on the consumers' buying decision. In the tourism industry, media may influence potential tourists in deciding their choice of destinations. The choice of destinations is often made based on the perception toward the tourism object, which cognitively and emotionally can be influenced by the advertisement that they watch, read, hear or see in 
the media. Rodriguez-Molina et al. (2015) argued that the destination image or perception from the tourists' point of view will be more positive when emotional messages are included in the website communication, and the individual is not overloaded with information.

The image of a tourism destination is a significant aspect in influencing tourists' decision on a certain destination. Souiden et al. (2017) analyzed the impact of the image of a destination on tourists' attitudes and visiting intention. The study revealed that the image of a certain destination acts as an antecedent toward the image of the destination, which will eventually be directly affecting the individual's attitude toward a destination. Sanchez et al. (2016) argued that tourists tend to have particular like or dislike toward certain destinations, which are caused by many aspects, including mainly from the information they get from the media. Certain favorability will likely to have a positive impact, and vice versa, tourists' animosity or dislike toward a particular destination will surely have impact on the intention to visit the destination. Kovathanakul (2015) analyzed the Central Northeastern Thailand Tourism Branding. The research analyzes the tourism branding in the region. The findings in the research show that quality awareness and cognitive image were important in the perspective of tourists. Moreover, brand communication is the most influential factor among tourists since the communication branding reassures tourists of the existence of an attraction.

The term "millennials" in this research refers to the generation often called as "Generation Y". There are a few versions of categorization of the age of this group, however, this study will refer to the age group from Strauss and Howe (2000), which define it as those who were born in 1982 and after. It remains unclear which year is the cut off for this generation as many experts still argue. For the purpose of this research, the respondents will comprise of those who are aged between 17-25 years old. This research will fill the gap in other findings, and contribute to the enrichment of understanding on how the social media plays its role in the tourism business. Souiden et al. (2017) argued that the tourists' decision on the destination is influenced by the image of the destination. The same case also argued by Sanchez et al. (2016), in the revelation that tourists tend to have particular like or dislike toward certain destination. Kovathanakul (2015) voiced the same findings, in the context of the tourism in Thailand. From that perception aspect, Tong (2013) has shown that media has a powerful role in shaping perception and influencing behavior. Dudensing et al. (2011) found out that the Internet's role in promoting tourism business is underestimated. Rodriguez-Molina (2015) revealed that the perception could be shaped through the message delivered from the media, in particular the Internet.

\section{Research method}

We gather information through the sampling of questionnaire to 220 respondents. Respondents are based in greater Jakarta (Jakarta, Bogor, Tangerang, Depok and Bekasi), with the age ranges from 17-25 years old. They have social media accounts and have been on holiday to places outside of their city at least once. Of all the respondents, there were only 203 samples eligible to be processed, of which $45 \%$ were female and 55\% were male. Samples were filtered by two conditions: First, the respondent should have experience in travelling for holiday. Second, the respondents should be users of at least one social media (Facebook, Instagram, Twitter, etc.). Sampling was accomplished using simple random sampling technique, which specifies subject to be researched by drawing a simple random sample directly from the population (Sekaran \& Bougie, 2016). These respondents have at least one social media account and have been on holiday to places outside of their cities at least once. This was the pre-condition set as eligible respondent. Collected samples were processed using SPSS, and were checked for validity and reliability, as the preliminary process. Next step after the validity and reliability, we have run the R Square and $t$ test. 


\section{Results and discussions}

Table 1 shows the results of the reliability and validity of the survey.

Table 1

Validity Test

Indicators

Corrected Item-Total

Correlation

i6 I source information for my holiday destination through social media

i15 Postings on social media influences considerations in choosing my holiday destination

i20 I believe that postings on social media describe the real information of tourism destination

0.491

i23 I trust postings on social media about tourism destination more than advertisements in main-

0.586

stream media

i24 I like postings on tourism destinations in social media more than in advertisements about them

0.536

As we can observe from the results of Table 1, all indicators are valid because each of the indicators is above 0.3 in corrected item-total correlation (Nunnally \& Bernstein, 1994).

Table 2

Reliability Test

\begin{tabular}{ccc}
\hline Cronbach's Alpha & Cronbach's Alpha Based on Standardized Items & N of Items \\
\hline .764 & .762 & 6 \\
\hline
\end{tabular}

Cronbach's Alpha test show that they were all above 0.6, which indicate they are reliable.

Table 3

Impact of Social Media on Millenial Tourists' Destination Choice

\begin{tabular}{lcccc}
\hline Model & $\mathrm{R}$ & $\mathrm{R}$ Square & Adjusted R Square & Std. Error of the Estimate \\
\hline 1 & $.994^{\mathrm{a}}$ & .989 & .989 & .118 \\
\hline a. Predictors: (Constant), I24, I15, I6, I20, I23 & & &
\end{tabular}

Table 3 shows that with Correlation Co-efficient (R) at 0.994 and the R Square at 0.989, the impact of social media on millennial tourists' choice of destination is at 0.989 . A significance test was then run for all the indicators with the result shown on Table 4.

Table 4

Significance Test

\begin{tabular}{|c|c|c|c|c|c|c|c|c|}
\hline \multirow[t]{2}{*}{ Model } & & \multicolumn{2}{|c|}{$\begin{array}{l}\text { Unstandardized Coeffi- } \\
\text { cients }\end{array}$} & \multirow{2}{*}{$\begin{array}{c}\text { Standardized Coef- } \\
\text { ficients } \\
\text { Beta } \\
\end{array}$} & \multirow[t]{2}{*}{$\mathrm{t}$} & \multirow[t]{2}{*}{ Sig. } & \multicolumn{2}{|c|}{ Collinearity Statistics } \\
\hline & & $\mathrm{B}$ & Std. Error & & & & Tolerance & VIF \\
\hline \multirow{6}{*}{1} & (Constant) & -.523 & .043 & & -12.179 & .000 & & \\
\hline & I6 & .084 & .023 & .082 & 3.643 & .000 & .112 & 8.911 \\
\hline & I15 & .135 & .015 & .100 & 8.762 & .000 & .438 & 2.284 \\
\hline & I 20 & .405 & .016 & .343 & 25.575 & .000 & .317 & 3.156 \\
\hline & I23 & .426 & .014 & .524 & 29.604 & .000 & .182 & 5.507 \\
\hline & I 24 & .061 & .012 & .073 & 5.144 & .000 & .283 & 3.537 \\
\hline
\end{tabular}

a. Dependent Variable: Y

The Sig. score for each variable shown on the table above is less than 0.05 , which means that all the $X$ variables have significant impacts towards $Y$. While for the $t$ test, every variable shows the score of greater than 1.96. This implies that all the $\mathrm{X}$ variables have significant impact towards $Y$. The VIF score for each variable is shown as $<10$. We can conclude that there is no multicollinearity. The regression equation can be shown as below:

$\mathrm{Y}=-0.523+0.084(\mathrm{I} 6)+0.135(\mathrm{I} 15)+0.405(\mathrm{I} 20)+0.426(\mathrm{I} 23)+0.061(\mathrm{I} 24)$ 
Theoretical implications from such findings are as below: First: This research yield similar revelation with Malik et. al (2016), Lin (2014) and Punyanunt-Carter et. al (2017), regarding the response of audience in the Internet and social media. Second; social media should be included into one of the important variable or tools when it comes to studies of any activities of promotion, especially with regards to the millennial target market. Social media is not only the Internet because it involves a two-way interaction. Users of social media are not passive, but they are active, meaning that they can be both the information feeder and consumer. This is in line with Felix et.al (2017). Authors argue the managerial implication of the study as followed: As shown in the R Square test, the impact of social media is very significant towards the millennials. This generation is very heavily impacted by the social media, and a message communicated through social media will most likely impact their decision making. Selling travel packages to younger customers at the age group of 17-25 years old will have to involve social media in the promotion plan.

\section{Conclusion}

Findings of this study can come into the conclusion that social media is a force to be reckoned in the map of mass communication tools for the millennials, especially in the tourism industry. The sights of people posting pictures of places they visit or food they eat on social media is something we see very massively nowadays. This study shows that such postings do not only serve as the self-actualization of the posters, but more than that, they serve as powerful tool to inform others about the destination, with the outcome of either animosity or favorability of such destination. On the other hand, those seeking information will also be informed through the social media of the destinations, and those who are undecided may also be impulsively influenced by the images and information they see on the social media. The $\mathrm{R}$ square of 98.9\% shows that social media has an extremely significant contribution and it cannot be ignored by anyone trying to influence the millennials. Traveling is a significant amount of expense from a personal financial issue, therefore most likely the potential tourists will dig deep, collect information and analyze before making decision about holiday spending. Therefore, the information and impression they collect from social media (postings on Facebook, Instagram, etc.) are only enough to impulsively influence them to have the intention to choose the destination. Whether they will actually choose and do action, it will depend on other factors, as pointed out by other study by Dudensing et al. (2011), which pointed it at the promotion. Kovathanakul (2015) suggested as depending on the branding, and Sanchez argued that animosity of tourists towards the destination could contribute to the decision making (2016), while Souiden et al. (2017) pointed out at the image of the destination.

This study also shows that social media needs to be considered as a significant tool in a tourism promotion. Respondents tend to believe that the information they see on social media about certain destinations is true. Therefore, stakeholders in the tourism business need to manage news, tweets, or any reviews in the social media regarding their business, because it may impact their business, in a good or bad way. However, further studies may be required to explore more about more relevant indicators.

\section{References}

Bialik, K., \& Matsa, K. E. (2017). Key trends in social and digital news media. Pew Research Center, 4. Dudensing, R. M., Hughes, D. W., \& Shields, M. (2011). Perceptions of tourism promotion and business challenges: A survey-based comparison of tourism businesses and promotion organizations. Tourism Management, 32(6), 1453-1462.

Felix, R., Rauschnabel, P. A., \& Hinsch, C. (2017). Elements of strategic social media marketing: A holistic framework. Journal of Business Research, 70, 118-126.

Kovathanakul, D. (2015). Central Northeastern Thailand Tourism Branding, Supporting the ASEAN Economic Community. Procedia Economics and Finance, 23, 291-297.

Lin, J. (2014). The effects of gratifications on intention to read citizen journalism news: The mediating effect of attitude. Computers in Human Behavior, 36, 129-137. 
Malik, A., Dhir, A., \& Nieminen, M. (2016). Uses and gratifications of digital photo sharing on Facebook. Telematics and Informatics, 33(1), 129-138.

Nunnally, J., \& Bernstein, I. (1994). Psychometric Theory 3rd edition (MacGraw-Hill, New York).

Punyanunt-Carter, N. M., De La Cruz, J. J., \& Wrench, J. S. (2017). Investigating the relationships among college students' satisfaction, addiction, needs, communication apprehension, motives, and uses \& gratifications with Snapchat. Computers in Human Behavior, 75, 870-875.

Rodríguez-Molina, M. A., Frías-Jamilena, D. M., \& Castañeda-García, J. A. (2015). The contribution of website design to the generation of tourist destination image: The moderating effect of involvement. Tourism Management, 47, 303-317.

Sánchez, M., Campo, S., \& Alvarez, M. D. (2018). The effect of animosity on the intention to visit tourist destinations. Journal of Destination Marketing \& Management, 7, 182-189.

Sekaran, U., \& Bougie, R. (2016). Research methods for business: A skill building approach. John Wiley $\&$ Sons.

Souiden, N., Ladhari, R., \& Chiadmi, N. E. (2017). Destination personality and destination image. Journal of Hospitality and Tourism Management, 32, 54-70.

Strauss, W., \& Howe, N. (2000). Millennials rising: The next great generation (p. 29). New York: Vintage Books.

Thai, N. T., \& Yuksel, U. (2017). Too many destinations to visit: Tourists' dilemma?. Annals of Tourism Research, 62, 38-53.

Tong, S. C. (2013). Media reputation in initial public offerings: A study of financial news coverage in Hong Kong. Public Relations Review, 39(5), 470-483.

World Travel \& Tourism Council. (2018). Travel \& Tourism: Economic Impact 2018 Albania. World Travel \& Tourism Council (WTTC).

Wang, X., Baesens, B., \& Zhu, Z. (2019). On the optimal marketing aggressiveness level of C2C sellers in social media: Evidence from china. Omega, 85, 83-93.

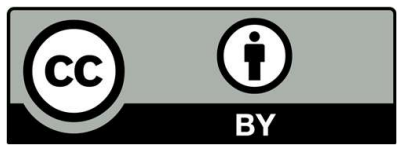

(C) 2019 by the authors; licensee Growing Science, Canada. This is an open access article distributed under the terms and conditions of the Creative Commons Attribution (CCBY) license (http://creativecommons.org/licenses/by/4.0/). 